\title{
CEE'S EXPORT INSTABILITY TOWARD EAST ASIAN MARKETS: EVIDENCE FROM PANEL ARDL MODELS
}

\author{
Shoiw-Mei TSENG \\ (Received: 7 January 2016; revision received: 8 August 2016; \\ accepted: 16 January 2017)
}

Exports play a significant role in the economic catching-up transition in Central and Eastern Europe (CEE). The East Asian market has emerged for CEE's exports not only because of its dynamic economy, but also because of the European debt crisis, the political tension between Ukraine and Russia, and the recent threat of terrorism. This study utilises panel ARDL models to estimate the long-run and short-run relationships between export instability and commodity concentration and geographic concentration. The datasets cover the 2004-2014 period for the trade of all the CEE countries with 10 East Asian marketplaces. The results of the causal relationships show significance in the long-run, but not in the short-run. This study suggests that the CEE export policy toward East Asia is likely to consider the impact of trade concentrations on export instability.

Keywords: Central and Eastern Europe, commodity concentration, East Asia, export instability, geographic concentration, panel ARDL

JEL classification indices: C33, F14, O57

Shoiw-Mei Tseng, Assistant Professor at the Department of International Business, I-Shou University, Kaohsiung City, Taiwan. E-mail: wisnia@isu.edu.tw 


\section{INTRODUCTION}

The economy of Central and Eastern Europe (CEE) ${ }^{1}$ has transitioned from import substitution to export expansion thanks to abundant foreign direct investment (FDI) (Bijsterbosch - Kolasa 2010; Medve-Bálint 2014). More specifically, European Union (EU) membership highlights CEE's external competitiveness in the catching-up process (Forgó - Jevčák 2015). The CEE export/import ratios increased significantly from 0.777 in 1999 to 1.0116 in 2014, about 30\% in growth. Between 1999 and 2014, these ratios increased for every country, ranging from a $10 \%$ in Romania to a $65 \%$ in Poland. Until 2014, exports outpaced imports in four countries (the Czech Republic, Hungary, Slovakia, and Slovenia). Although the speed of each country's path is different, exports are widely acknowledged as an engine of economic growth in CEE (Awokuse 2007; Weber 2011; Borgersen - King 2014).

This international openness, however, is said to be Europeanisation instead of globalisation. Martin (1998) pointed out that CEE is integrated in the international economy with limits on globalisation. It is not surprising that CEE international trade almost ends up in the EU, as Fligstein - Merand (2002) discussed the issue of globalisation or Europeanisation for the EU economy. The EU percentage of CEE foreign trade averaged about $75 \%$ in 1999-2014, of which exports accounted for more than $80 \%$ before $2004 .^{2}$ Although the 15 original member states of the EU (EU15) decrease the percentage of CEE foreign trade, the intra-CEE trade almost replaces it. The EU15 percentage of CEE imports decreased from $62 \%$ in 1999 to $53 \%$ in 2014; meanwhile, intra-CEE trade increased from $10 \%$ to $19 \%$. In total, the EU percentage of CEE imports remains steady at around 70\%. CEE exports spread only slightly beyond the EU, from $18 \%$ in 1999 to $24 \%$ in 2014 . Silgoner et al. (2015) proposed that CEE countries must pursue a suitable export strategy and diversification of products and markets, when the EU economy is predicted to grow slowly. Accordingly, this study pays attention to the potential for CEE exports in the extra EU.

1 In the context of this paper, CEE countries are member states of the expanded European Union: Bulgaria, the Czech Republic, Estonia, Hungary, Latvia, Lithuania, Poland, Romania, Slovenia, and Slovakia. Croatia, a new member of the EU, is not dealt with here.

2 Detailed country tables are available from the author. 
The extra-EU markets for CEE exports are dominated by the Commonwealth of Independent States (CIS), ${ }^{3}$ East Asia (EA), ${ }^{4}$ and other Asian countries. These three regions have the most positive significance on the Pearson correlation coefficient between the percentage of CEE exports and years in 1999-2014. CEE's historical ties with the CIS are a great boost to exports, for example, with the Council for Mutual Economic Assistance (CMEA) as the former Soviet-led economic bloc. After the global financial crisis in 2008, CEE exports to EA rapidly increased. The EA share of CEE exports averaged an $8.81 \%$ growth in 2009-2014, but $-0.69 \%$ for the CIS and $0.9 \%$ for other Asian countries. Shepotylo (2013) concluded that CIS countries were vulnerable to trade shocks after comparing the export diversification in CEE and CIS. Under the increasing uncertain factors of foreign trade in Europe, such as the European debt crisis, the political tension between Ukraine and Russia, the refugees flood, and the terrorism threat in Europe, the dynamic EA could be a superior region for CEE export expansion. Korhonen (2012) emphasised that today Asia is not just a geographic concept, but also has been redefined as a global political and economic core area. An economically dynamic East Asia is the main reason for the Asia-Europe Meeting (ASEM) established in 1996 (Japan Center for International Exchange - University of Helsinki 2006). Poncet - Mayneris (2013) noted that penetrating Asian markets have become a priority for European firms and governments, despite many substantial difficulties delineated in the case of French firms. However, Birzins (2004) asserted that the study of bilateral relations between CEE and EA is a greenfield because of historical, political, and geographic circumstances. Thus, the market fluctuation in CEE exports to EA is the main aim of this study, and is referred to as export instability.

A voluminous literature has examined export instability since the 1950 s because of its significant role in economic growth (Athukorala - Huynh 1987; Love 1987; Herzer - Nowak-Lehnmann 2006). Particularly, the export instability implies an important policy strategy to stimulate trade activities (Newfarmer et al. 2009). Samen (2010) even assessed that export concentrations could cause serious economic and political risks. Thus, many econometric analyses attempt to investigate the effects of export instability and provide policy implications. However, Love (1987) elaborated on the empirical studies of export instability over several decades and found no consensus about the consequences and causes of export instability. In a similar vein, Malhotra - Pinky (2015) commented that explana-

3 This study calculates the total for 12 countries, including Armenia, Azerbaijan, Belarus, Georgia, Kyrgyzstan, Kazakhstan, Moldova, Russia, Tajikistan, Turkmenistan, Ukraine, and Uzbekistan.

4 The East Asian markets are represented by 10 countries in this study: China, Hong Kong, Indonesia, Japan, South Korea, Malaysia, Singapore, Thailand, Taiwan, and Vietnam. 
tory variables to determine export instability differ from country to country in the literature. Nevertheless, Stein (1977) stated that commodity and geographic concentrations have generally been regarded as the major causes of export instability. Both commodity concentration and geographic concentration appear as explanatory variables of export instability from the early studies by Massell (1964) and Love (1985) to the recent papers of Hamid (2010) and Malhotra - Pinky (2015). Some studies focus on comparative advantages of commodity concentration for export instability, for example Katrak (1973), MacBean - Nguyen (1980), Love (1986), Tegene (1990), and Gouvea (2016). The recent studies emphasise the effects of external trade shocks on geographic concentration, for example Kali et al. (2007), Malik -Temple (2009), Agosin et al. (2012), and Kamat (2016).

This study applies the common causal concept between export instability and these concentrations to the level of the EA region from the CEE perspective; most previous studies examined export instability at the level of the global market. In other words, there seems to be a prima facie causal link between export instability and commodity and geographic concentrations for CEE toward the EA region. On the commodity side, CEE industrial restructuring has resulted in a pattern of export commodities. Leitner - Stehrer (2014) demonstrated that between 1995 and 2007, the vertical specialisation share in exports intensified greatly in CEE as a result of its rapid productivity improvements. Parteka (2013b) confirmed the positive relationship between the commodity diversification of trade and economic development levels in CEE across the years 1988-2010. On the geography side, China's rise has attracted worldwide attention, and China has exploited the international trade opportunity particularly in the EA region, seen in the numerous papers on the China threat theory published since the 1990s (Al-Rodhan 2007). Cadot et al. (2014) detected the large effects of China's rise on geographic concentrations of OECD imports. ${ }^{5}$ The CEE country-specific studies of commodity concentration and geographic concentration could be found recently in Parteka (2013a) for Poland and Laskiene - Venckuviene (2014) for Lithuania. Therefore, the present study attempts to examine the link between export instability and the two forms of concentration with various effects in the sample countries.

The rest of this paper is organised as follows. Section 2 discusses the methodology. First, the key variables, export instability, commodity concentration, and geographic concentration, are defined by mathematical formulas. Then, the econometric technique is introduced with an emphasis on dynamic modelling for causal relationships of the variables. Section 3 shows the modelling. Long-run and shortrun relationships are analysed to evaluate the effects of the two concentrations on export instability among different sample models. Section 4 concludes.

\footnotetext{
Organization for Economic Co-Operation and Development.
} 


\section{METHODOLOGY}

Various measurements of export instability (XI) have been studied since the 1950s. For example, Malhotra - Pinky (2012) could compare 9 different calculations in the literature for India's XI. Cariolle - Goujon (2013) criticised the measures of export instability because of its complex and multidimensional characteristics. The present study, following Massell (1970) and Naya (1973), defines XI as the deviation from the exponential trend of merchandise export earnings, instead of linear or moving average forms. The exponential trend is the most widely used measure in time series following Lee (1977), MacBean - Nguyen (1980), Love (1986), and Malhotra - Pinky (2015). Indeed, the major motivation of this study concerns the dynamic growth of CEE-EA exports, not the absolute increment.

$$
X I_{i j t}=\frac{X_{i j t}-\hat{X}_{i j t}}{X_{i j t}},
$$

where $X I_{i j t}$ is the export value of country $i$ to country $j$ in year $t$ and $\hat{X}_{i j t}$ is the exponential trend value of country $i$ export to country $j$ in year $t$.

Usually, the Gini-Hirschman coefficient is applied to delineate the commodity concentration (CC) and the geographic concentration (GC) as follows (Love 1979):

$$
C C_{i k t}=100 \sqrt{\sum_{k=1}^{n}\left(\frac{X_{i k t}}{X_{i t}}\right)^{2}},
$$

where $X_{i k t}$ is the commodity $k$ value in country $i$ export to a given region in year $t$ and $X_{i t}$ is $i$ country's total export value in a given region in that year.

$$
G C_{i j t}=100 \sqrt{\sum_{j=1}^{n}\left(\frac{X_{i j t}}{X_{i t}}\right)^{2}},
$$

where $X_{i j t}$ is the export value of country $i$ to country $j$ of a given region in year $t$. A higher coefficient represents an increased trade concentration in a few commodities or partners.

This study uses annual data on exports in euros from the Eurostat database, Easy Comext, covering the period of 2004-2014. The commodities are identified with the two-digit codes of the Harmonised System. The starting year is 2004 because this is the year many CEE countries became members of the EU, although Bulgaria and Romania joined the EU slightly later, in 2007. CEE's external trade policy tends to be coherent under the EU schema, which may eliminate some research considerations of bilateral trade conditions. In contrast, the EA countries in 
this study are diverse, in particular China's rise. Wooldridge (2010) advocated the panel data model for causal relationships of variables in dynamics and the econometric crux of ceteris paribus. Hsiao (2014) described many merits of panel data analysis, including the construction of more complicated behavioural hypotheses, increasing degrees of freedom, lessening the problem of multicollinearity, uncovering dynamic relationships, controlling the impact of omitted variables, providing micro-foundations for aggregate data analysis, and simplifying computation and statistical inference, which are considered in this study. Thus, this study utilises the panel data technique to estimate the individual export of CEE countries with each EA marketplace. The balanced dataset is a two-dimensional matrix in which one dimension is represented by the $10 \mathrm{CEE}$ countries and the other dimension is the 11-year time period. The 10 destination countries in EA formulate the 10 panel data models for the intercountry comparison.

Further, this study follows Engle - Granger's (1987) co-integration theorem to avoid spurious regressions and to highlight the long-run and short-run relationships between export instability and concentrations. Pesaran - Shin (1998) rehabilitated autoregressive distributed lagged (ARDL) models to examine the co-integrated relationships between variables. More specifically, Pesaran et al. (1999) exploited the pooled mean group (PMG) estimation, which takes the cointegration form of the simple ARDL model and adapts it to the panel setting by allowing all coefficients and error variances to differ across countries. The panel ARDL (p,q,q) model of this study can be written as:

$$
X I_{i t}=\alpha_{i}+\sum_{m=1}^{p} \lambda_{i m} X I_{i, t-m}+\sum_{m=0}^{q} \delta_{1 i m} C C_{i, t-m}+\sum_{m=0}^{q} \delta_{2 i m} G C_{i, t-m}+\varepsilon_{i t},
$$

where $X I_{i t}$ is the dependent variable, $C C_{i t}$ and $G C_{i t}$ are dynamic regressors, $\alpha_{i}$ is the constant, and $\varepsilon_{i t}$ is the disturbance for $i=1,2,3 \ldots .10$ cross-sectional CEE countries observed for dated periods $t=2004,2005, . .2014$. $p$ is the number of lags of $X I . q$ is the number of lags of $C C$ and $G C . \lambda_{i m}, \delta_{1 i m}$ and $\delta_{2 i m}$ are coefficients of the lagged $X I_{i, t-m}, C C_{i, t-m}$, and $G C_{i, t-m}$, respectively.

Equation (4) can be reparametrised as (HIS 2015):

$$
\begin{gathered}
\Delta X I_{i t}=\alpha_{i}+\varphi_{i} E C T_{i t}+\sum_{m=1}^{p-1} \lambda_{i m}^{*} \Delta X I_{i, t-m}+\sum_{m=0}^{q-1} \delta_{1 i m}^{*} \Delta C C_{i, t-m}+ \\
+\sum_{m=0}^{q-1} \delta_{2 i m}^{*} \Delta G C_{i, t-m}+\varepsilon_{i t}
\end{gathered}
$$

where $E C T_{i t}=X I_{i, t-1}-\beta_{1 i}^{\prime} C C_{i t}-\beta_{2 i}^{\prime} G C_{i t}$ is the error-correction term (ECT). 
The minimum Schwarz Bayesian criterion (SBC) is used to determine the appropriate lag lengths, following Pesaran - Shin's (1998) experiments that in small samples the ARDL-SBC performs better than the Akaike information criterion. The maximum number of lags for each variable is set at two on the consideration of degrees of freedom for the small samples of annual data. The ECT coefficient must be negative, not lower than -2 , and at the $5 \%$ significance level, to ensure a long-run relationship (Loayza - Ranciere 2006). Within the uniform criteria of a simple market model, this study compares the ten equations for each individual sample country in EA.

Although an ARDL model could have mixed orders of integration for variables (Pesaran - Shin 1998), this study conservatively adopts the panel unit root test to confirm the stationarity of the variables. There are two types of panel unit root processes, a common unit root of Levin, Lin, and Chu (LLC) and Breitung tests and an individual unit root of Im, Pesaran, and Shin (IPS), ADF-Fisher and PP-Fisher tests (Baltagi 2013). All tests take non-stationarity as null. This study uses the automatic lag length selection based on the SBC and the Newey-West automatic bandwidth selection with the Bartlett kernel. The two-way Pearson correlation test is used to determine an intercept with time trends in the panel unit root process. The Pearson correlation coefficient between a variable and years ranges from -1 to +1 , where 1 is a total positive correlation, 0 is no correlation, and -1 is a total negative correlation (Davis - Pecar 2013).

The PMG is an encompassing model of long-run and short-run effects that uses a panel of cross-country and time-series observations. The PMG also allows for individual cross-section short-run coefficients in detail with Eviews_9 software. Table 1 lists the coding used in this study, including the abbreviations of sample countries and panel ARDL models. Note that the selected 10 EA countries

Table 1.Codes of sample countries and models

\begin{tabular}{|c|c|c|c|c|}
\hline \multicolumn{2}{|c|}{ Cross-sections: CEE } & \multicolumn{2}{|c|}{ Destination country: EA } & \multirow[t]{2}{*}{ Panel ARDL model } \\
\hline Country & Code & Country & Code & \\
\hline Bulgaria & BG & China & $\mathrm{CN}$ & $\mathrm{CN}(\mathrm{p}, \mathrm{q}, \mathrm{q})$ \\
\hline Czech Republic & $\mathrm{CZ}$ & Hong Kong & HK & $\mathrm{HK}(\mathrm{p}, \mathrm{q}, \mathrm{q})$ \\
\hline Estonia & $\mathrm{EE}$ & Indonesia & ID & $\operatorname{ID}(p, q, q)$ \\
\hline Hungary & $\mathrm{HU}$ & Japan & JP & $J P(p, q, q)$ \\
\hline Lithuania & LT & South Korea & KR & $\mathrm{KR}(\mathrm{p}, \mathrm{q}, \mathrm{q})$ \\
\hline Latvia & LV & Malaysia & MY & $M Y(p, q, q)$ \\
\hline Poland & PL & Singapore & SG & $\mathrm{SG}(\mathrm{p}, \mathrm{q}, \mathrm{q})$ \\
\hline Romania & RO & Thailand & $\mathrm{TH}$ & $\mathrm{TH}(\mathrm{p}, \mathrm{q}, \mathrm{q})$ \\
\hline Slovenia & SI & Taiwan & TW & $\mathrm{TW}(\mathrm{p}, \mathrm{q}, \mathrm{q})$ \\
\hline Slovakia & SK & Vietnam & $\mathrm{VN}$ & $\mathrm{VN}(\mathrm{p}, \mathrm{q}, \mathrm{q})$ \\
\hline
\end{tabular}


are listed according to the percentage of CEE exports in EA. The Philippines is excluded, although its market size is large owing to its population of about 100 million and English is one of the official languages, which is favourable for international business.

In sum, this study would not make a hypothesis of those effects, agreeing with MacBean - Nguyen's (1980) view of no clear-cut relationship between export instability and the degree of concentration. Also, this study does not debate the methodology issue of the relationships between $\mathrm{XI}, \mathrm{CC}$, and GC as in previous studies reviewed in detail by Love (1987), but instead argues for the comparison of these relationships in different destination countries through the same method of the panel ARDL model.

\section{EMPIRICAL RESULTS}

First, Table 2 displays the Pearson correlation coefficients between the variables and years for individual CEE countries toward EA markets. The CCs and GCs show significant correlations with the time trends, while the XIs are close to constant. Accordingly, the following panel unit root tests assume that the CCs and GCs have individual intercepts and trends, and the XIs have individual intercepts (HIS 2015).

Table 3 reports the results of the panel unit root tests, which suggest that CCs and GCs are stationary of order I(1), while XIs seem I(0). These mixed orders of integration confirm that the panel ARDL approach is better than the traditional panel co-integration test.

Table 2. Pearson correlation coefficients between variables and years

\begin{tabular}{lrrrrrrrrrr}
\hline Variable & BG & CZ & EE & HU & \multicolumn{1}{c}{ LT } & LV & PL & RO & \multicolumn{1}{c}{ SI } & \multicolumn{1}{c}{ SK } \\
CC_EA & -0.3413 & -0.5736 & -0.4120 & -0.3534 & -0.4685 & -0.6500 & 0.0749 & -0.3302 & -0.1880 & 0.8957 \\
GC_EA & 0.2712 & 0.8512 & -0.0808 & 0.6475 & -0.2941 & -0.5252 & -0.4955 & 0.6167 & 0.4643 & 0.9279 \\
XI_CN & 0.0524 & 0.0160 & -0.1379 & -0.0239 & 0.0020 & -0.0061 & 0.0068 & -0.0387 & -0.0290 & 0.0581 \\
XI_HK & 0.0129 & 0.0058 & 0.0301 & 0.0222 & 0.0018 & 0.0145 & 0.0008 & -0.0100 & -0.0387 & -0.0781 \\
XI_ID & 0.0227 & 0.0038 & -0.2280 & 0.0783 & -0.4140 & 0.0884 & -0.0724 & -0.0705 & 0.1257 & 0.0312 \\
XI_JP & -0.0521 & -0.0205 & -0.0887 & 0.0268 & 0.0217 & -0.0021 & 0.0027 & -0.0147 & 0.0192 & 0.0484 \\
XI_KR & 0.0792 & -0.0263 & -0.0541 & -0.0426 & -0.1327 & 0.0034 & -0.0397 & -0.1677 & 0.0387 & -0.0115 \\
XI_MY & 0.0475 & 0.0040 & 0.0189 & 0.0801 & -0.0685 & 0.1356 & 0.0058 & 0.0054 & 0.0435 & 0.0171 \\
XI_SG & 0.2724 & 0.0035 & 0.0364 & 0.1385 & 0.2261 & -0.0774 & -0.0698 & -0.0026 & 0.0047 & 0.0670 \\
XI_TH & -0.1071 & -0.0217 & -0.1305 & 0.0636 & -0.0261 & -0.0455 & -0.0833 & -0.0696 & -0.0092 & 0.0464 \\
XI_TW & -0.0107 & 0.0127 & -0.1056 & -0.0276 & -0.0901 & 0.0811 & -0.0059 & -0.0661 & -0.0948 & 0.0311 \\
XI_VN & 0.0173 & 0.0076 & 0.0576 & 0.0344 & 0.0223 & -0.0169 & -0.0112 & -0.0960 & -0.7925 & -0.0122 \\
\hline SI_C
\end{tabular}

Source: Autor's own work. 
Table 3. Results of panel unit root tests

\begin{tabular}{|c|c|c|c|c|c|}
\hline \multirow{2}{*}{ Series } & \multicolumn{2}{|c|}{ Common unit root process_t-Stat. } & \multicolumn{3}{|c|}{ Individual unit root process_ t-Stat. } \\
\hline & LLC & Breitung & IPS & ADF-Fisher & PP-Fisher \\
\hline $\mathrm{CC}$ & $-5.6001 * *$ & 0.6652 & -0.7336 & 28.0116 & $37.9659 * *$ \\
\hline GC & $-2.5086^{* *}$ & -0.0248 & 0.1122 & 20.9893 & 23.0667 \\
\hline XI_CN & $-3.8578 * *$ & & $-2.4857 * *$ & $37.0303 *$ & 29.9352 \\
\hline XI_HK & $-5.2097 * *$ & & $-3.9039 * *$ & $49.8354 * *$ & $52.9727 * *$ \\
\hline XI_ID & $-15.2249 * *$ & & $-6.6204 * *$ & $60.9562 * *$ & $70.7993 * *$ \\
\hline XI_JP & $-6.1904 * *$ & & $-3.7823 * *$ & $50.3992 * *$ & $34.5346^{*}$ \\
\hline XI_KR & $-5.6029 * *$ & & $-3.7914 * *$ & $50.1224 * *$ & $37.7151 * *$ \\
\hline XI_MY & $-6.8027 * *$ & & $-4.2869 * *$ & $52.9117 * *$ & $46.2635 * *$ \\
\hline XI_SG & $-6.4591 * *$ & & $-4.5964 * *$ & $57.7550 * *$ & $61.2897 * *$ \\
\hline XI_TH & $-8.5748 * *$ & & $-5.2222 * *$ & $63.4046^{* *}$ & $60.2795 * *$ \\
\hline XI_TW & $-6.9631 * *$ & & $-4.1205^{* *}$ & $52.2613 * *$ & $54.4586^{* *}$ \\
\hline XI_VN & $-6.5706^{* *}$ & & $-3.7698 * *$ & $51.4793 * *$ & $60.9301 * *$ \\
\hline$\Delta \mathrm{CC}$ & $-10.6660 * *$ & $-3.2317 * *$ & $-2.5852 * *$ & $55.0348 * *$ & $86.3693 * *$ \\
\hline$\Delta \mathrm{GC}$ & $-7.5796 * *$ & $-3.6230 * *$ & $-1.7567 *$ & $42.7921 * *$ & $81.7480 * *$ \\
\hline$\Delta \mathrm{XI} C \mathrm{CN}$ & $-9.1648 * *$ & & $-4.7805^{* *}$ & $62.0332 * *$ & $64.7505^{* *}$ \\
\hline DXI_HK & $-9.8940 * *$ & & $-6.6144 * *$ & $79.3517 * *$ & $87.1052 * *$ \\
\hline DXI_ID & $-16.3260 * *$ & & $-9.8961 * *$ & $103.3740^{* *}$ & $122.2860 * *$ \\
\hline DXI_JP & $-9.0892 * *$ & & $-4.5231 * *$ & $58.7395 * *$ & $52.7158 * *$ \\
\hline$\Delta \mathrm{XI}$ KRR & $-7.9504 * *$ & & $-4.2026 * *$ & $56.8553 * *$ & $51.5337 * *$ \\
\hline$\Delta$ XI_MY & $-10.6804 * *$ & & $-5.9010 * *$ & $73.1496 * *$ & $80.6462 * *$ \\
\hline$\Delta \mathrm{XI} \_\mathrm{SG}$ & $-9.0113 * *$ & & $-5.2346^{* *}$ & $68.3529 * *$ & $96.3352 * *$ \\
\hline$\Delta$ XI_TH & $-12.3812 * *$ & & $-7.1739 * *$ & $86.0991 * *$ & $114.7300^{* *}$ \\
\hline$\Delta X I \_T W$ & $-9.3284 * *$ & & $-4.8481 * *$ & $63.1804 * *$ & $105.9790 * *$ \\
\hline$\Delta \mathrm{XI} V \mathrm{VN}$ & $-12.0387 * *$ & & $-6.8033 * *$ & $82.8251 * *$ & $122.4260 * *$ \\
\hline
\end{tabular}

Note: $\Delta$ denotes first differences. $* * 1 \%$ significance level; * $5 \%$ significance level.

Source: Author's own work.

Table 4 presents the possible panel ARDL (p,q,q) models according to the SBC values and ECT coefficients with p-values. Most of the optimal models were selected based on the minimum SBC. For the ECT requirements, ID $(2,1,1)$ and KR $(2,1,1)$ are better than ID $(2,2,2)$ and KR $(1,2,2)$, respectively.

Table 5 reports the results of the panel ARDL models, which indicate that most estimates are strongly significant in the long-run equations, but only a few in the short-run equations. In line with Love's (1987) arguments, the results suggest properties of simplicity, that there are causal relationships between export instability and trade concentrations, but with different effects among the ten EA countries. 
Table 4. Possible panel ARDL(p,q,q) models

\begin{tabular}{|c|c|c|c|}
\hline Model & $\mathrm{SBC}$ & ECT Coefficient & Selected \\
\hline $\mathrm{CN}(1,1,1)$ & 8.8389 & $-0.4680 * *$ & \\
\hline $\mathrm{CN}(1,2,2)$ & 7.8697 & $-0.7938 * *$ & () \\
\hline $\mathrm{CN}(2,1,1)$ & 8.0249 & $-0.5536^{* *}$ & \\
\hline $\operatorname{HK}(1,1,1)$ & 9.6560 & $-0.8884 * *$ & \\
\hline $\mathrm{HK}(1,2,2)$ & 9.2105 & $-0.8458 * *$ & \\
\hline $\operatorname{HK}(2,1,1)$ & 8.5368 & $-1.4352 * *$ & \\
\hline $\operatorname{HK}(2,2,2)$ & 7.9570 & $-1.8488 * *$ & () \\
\hline $\mathrm{ID}(1,1,1)$ & 10.6091 & $-0.7872 * *$ & \\
\hline $\operatorname{ID}(1,2,2)$ & 10.0343 & $-0.7041 * *$ & \\
\hline $\mathrm{ID}(2,1,1)$ & 9.8431 & $-0.7932 *$ & (2) \\
\hline $\mathrm{ID}(2,2,2)$ & 9.8403 & -2.0055 & \\
\hline $\mathrm{JP}(1,1,1)$ & 8.8005 & $-0.6575 * *$ & \\
\hline $\mathrm{JP}(1,2,2)$ & 8.1791 & $-0.7714 * *$ & \\
\hline $\mathrm{JP}(2,1,1)$ & 7.9704 & $-0.8949 * *$ & () \\
\hline $\mathrm{JP}(2,2,2)$ & 8.0526 & $-1.0661 * *$ & \\
\hline $\mathrm{KR}(1,1,1)$ & 9.8259 & $-0.5189 * *$ & \\
\hline $\mathrm{KR}(1,2,2)$ & 8.4431 & -0.1293 & \\
\hline $\mathrm{KR}(2,1,1)$ & 8.9207 & $-0.9020 * *$ & (a) \\
\hline $\operatorname{MY}(1,1,1)$ & 10.4232 & $-0.9320 * *$ & \\
\hline $\mathrm{MY}(1,2,2)$ & 9.8739 & $-1.1305^{* *}$ & \\
\hline $\operatorname{MY}(2,1,1)$ & 9.1788 & $-1.2860 * *$ & (a) \\
\hline $\mathrm{MY}(2,2,2)$ & 9.3348 & $-1.5526^{* *}$ & \\
\hline $\mathrm{SG}(1,1,1)$ & 10.5913 & $-0.6000 * *$ & \\
\hline $\mathrm{SG}(1,2,2)$ & 9.9106 & $-0.9327 * *$ & \\
\hline $\mathrm{SG}(2,1,1)$ & 9.6234 & $-1.3351 * *$ & \\
\hline $\mathrm{SG}(2,2,2)$ & 9.3630 & $-0.8643 * *$ & (0) \\
\hline $\mathrm{TH}(1,1,1)$ & 10.3282 & $-1.0848 * *$ & \\
\hline $\mathrm{TH}(1,2,2)$ & 8.8148 & $-0.9933^{*}$ & (0) \\
\hline $\mathrm{TH}(2,1,1)$ & 9.5744 & $-1.2053 * *$ & \\
\hline $\mathrm{TH}(2,2,2)$ & 9.3783 & $-1.8796^{*}$ & \\
\hline $\operatorname{TW}(1,1,1)$ & 9.8973 & $-0.9292 * *$ & \\
\hline $\operatorname{TW}(1,2,2)$ & 8.8323 & $-0.6891 * *$ & (a) \\
\hline $\operatorname{TW}(2,1,1)$ & 9.2318 & $-1.1832 * *$ & \\
\hline $\mathrm{VN}(1,1,1)$ & 10.5776 & $-0.9170 * *$ & \\
\hline $\mathrm{VN}(1,2,2)$ & 10.1765 & $-0.8125 * *$ & \\
\hline $\mathrm{VN}(2,1,1)$ & 9.8687 & $-0.9223 * *$ & \\
\hline $\mathrm{VN}(2,2,2)$ & 9.4270 & $-1.8111^{* *}$ & () \\
\hline
\end{tabular}

Note: ** $1 \%$ significance level; * 5\% significance level.

Source: Author's own work. 
Table 5. Results of panel ARDL models with the effects of CCs and GCs on XIs

\begin{tabular}{lcccccr}
\hline \multirow{2}{*}{ Model } & \multicolumn{2}{c}{ Long-Run Equation } & \multicolumn{2}{c}{ Short-Run Equation } & & \\
\cline { 2 - 6 } & $\mathrm{CC}$ & $\mathrm{GC}$ & $\Delta \mathrm{CC}$ & $\Delta \mathrm{GC}$ & $\Delta \mathrm{CC}(-1)$ & $\Delta \mathrm{GC}(-1)$ \\
\hline $\mathrm{CN}(1,2,2)$ & $-2.1916^{* *}$ & $3.5856^{* *}$ & 2.5076 & 0.5347 & 0.7070 & 0.2436 \\
$\mathrm{HK}(2,2,2)$ & $0.1560^{* *}$ & $0.4080^{* *}$ & -1.6433 & 3.1619 & 0.0652 & -1.4574 \\
$\mathrm{ID}(2,1,1)$ & 0.1525 & $-2.3975^{* *}$ & 0.1732 & -4.5613 & & \\
$\mathrm{JP}(2,1,1)$ & $1.1627^{*}$ & $-2.0017^{* *}$ & 1.1775 & -0.8884 & & \\
$\mathrm{KR}(2,1,1)$ & $2.4762^{* *}$ & -0.1745 & -0.6611 & -1.0248 & & \\
$\mathrm{MY}(2,1,1)$ & -0.0459 & $-1.3380^{* *}$ & 1.1333 & -2.1433 & & \\
$\mathrm{SG}(2,2,2)$ & $-5.1755^{* *}$ & $7.0945^{* *}$ & $11.5819^{*}$ & $-15.0482^{* *}$ & 5.1151 & -3.6443 \\
$\mathrm{TH}(1,2,2)$ & $6.1768^{* *}$ & $-2.6999^{* *}$ & -4.8488 & 2.0371 & $-7.3034 * *$ & 3.8453 \\
$\mathrm{TW}(1,2,2)$ & $-3.1501^{* *}$ & $1.3503^{* *}$ & 4.3954 & -3.2884 & 4.3398 & -0.3808 \\
$\mathrm{VN}(2,2,2)$ & $-0.5105^{*}$ & -0.1034 & -5.6198 & 5.0871 & -2.2660 & 4.4475 \\
\hline
\end{tabular}

Note: ** $1 \%$ significance level; * $5 \%$ significance level.

Source: Author's own work.

In the long-run relationships, most CCs and GCs have significant impacts on XIs. Insignificant CC coefficients are shown for Indonesia and Malaysia at the $5 \%$ significance level and for the GCs in South Korea and Vietnam. These results suggest that there is some commodity particularity for CEE exports in Indonesia and Malaysia. Likewise, South Korea and Vietnam probably have specific relations with CEE countries. Indeed, Vietnam has historically participated in the CMEA since 1978, the only country in EA. Recently, the prudent doimoi policy has attracted FDI in catching up with China since the 1990s (Welle-Strand et al. 2013). The tremendous FDI by South Korea in CEE shows that South Korea aims to penetrate the EU market (Matura 2014), as a result of promoting exports to CEE, but there are erratic fluctuations in imports. The EU-South Korea Free Trade Agreement (FTA) has been in force since 2011, the EU's first trade deal with an Asian country.

Regarding the effects, negative signs for CCs are shown for China, Singapore, Taiwan, and Vietnam, while the GCs are positive for China, Hong Kong, Singapore, and Taiwan. Interestingly, China, Hong Kong, Singapore, and Taiwan, the so-called Greater China loosely defined by Zhang (2005), take a synchronous effect, except for a positive CC for Hong Kong. The two strong economies, China and Japan, have exactly reverse effects on the CCs and GCs, suggesting very disparate marketplaces for CEE's exports. China cooperates more broadly with CEE than Japan, such as the institution of Secretariat for Cooperation between China and Central and Eastern European Countries established in 2012, although the cooperation of the Visegrad Group plus Japan started in 2003. The recent Chinese 
Table 6. Individual cross-country coefficients and p-values in the short-run equations

\begin{tabular}{|c|c|c|c|c|c|c|c|c|c|c|}
\hline Model & $\mathrm{BG}$ & $\mathrm{CZ}$ & $\mathrm{EE}$ & $\mathrm{HU}$ & LT & LV & $\mathrm{PL}$ & $\mathrm{RO}$ & SI & SK \\
\hline \multicolumn{11}{|l|}{$\mathrm{CN}(1,2,2)$} \\
\hline$\Delta \mathrm{CC}$ & 1.1558 & 5.8754 & $10.5649^{* *}$ & 5.0950 & 1.3785 & $3.5851^{*}$ & $-3.9966^{* *}$ & $*-1.3634$ & -1.4558 & $4.2369^{* *}$ \\
\hline$\Delta \mathrm{GC}$ & -0.8488 & 2.3852 & $2.7769^{*}$ & -1.9410 & -2.2170 & $-3.3000^{* *}$ & $-1.0589^{* *}$ & $* 4.8652^{*}$ & 2.7788 & $1.9071^{* *}$ \\
\hline$\Delta \mathrm{CC}(-1)$ & -2.1804 & 2.8773 & 0.4893 & 1.0509 & 0.4218 & 2.8357 & $-6.0875^{* *}$ & $2.5622^{* *}$ & * 4.6659 & $0.4353^{*}$ \\
\hline$\Delta \mathrm{GC}(-1)$ & 4.3094 & 4.0275 & 0.3063 & -1.4914 & $-0.8008^{*}$ & $-3.2194^{*}$ & $-2.1199^{* *}$ & 0.9422 & -0.9389 & $1.4211^{* *}$ \\
\hline \multicolumn{11}{|l|}{$\operatorname{HK}(2,2,2)$} \\
\hline$\Delta \mathrm{CC}$ & -7.2387 & $-6.2186^{* *}$ & -0.6820 & 6.6381 & $1.1885^{* *}$ & $-5.3448^{* *}$ & $-6.4468^{*}$ & -10.5403 & $8.5724^{* *}$ & * $3.6387^{*}$ \\
\hline$\Delta \mathrm{GC}$ & 5.5682 & $-4.3011^{* *}$ & -0.4598 & $-3.9203^{* *}$ & $*-0.6107^{* *}$ & $1.8740^{* *}$ & * $9.1551^{*}$ & 12.8498 & $14.6527^{* *}$ & $*-3.1888^{*}$ \\
\hline$\Delta \mathrm{CC}(-1)$ & -9.3751 & $7.0161^{* *}$ & $8.0382^{* *}$ & 1.6291 & $0.5155^{* *}$ & $-2.6855^{*}$ & 2.3496 & 2.9098 & $-8.1170^{* *}$ & $*-1.6290$ \\
\hline$\Delta \mathrm{GC}(-1)$ & 9.4091 & $-13.3010^{* *}$ & $*-8.0449^{* *}$ & -5.3148 & $-0.3790^{* *}$ & $1.4635^{*}$ & $-3.9553^{* *}$ & $*-7.0540$ & $11.7100^{* *}$ & * 0.8923 \\
\hline \multicolumn{11}{|l|}{$\mathrm{ID}(2,1,1)$} \\
\hline$\Delta \mathrm{CC}$ & 8.9234 & -1.9916 & -4.3358 & 1.3835 & -4.3180 & -2.6643 & 0.0039 & 11.8193 & -8.4304 & 1.3415 \\
\hline$\Delta \mathrm{GC}$ & -6.9348 & $-14.1998^{*}$ & 0.5860 & -6.9861 & 8.8203 & -10.1874 & $9.1958^{* *}$ & $*-22.0151$ & -3.5187 & -0.3732 \\
\hline \multicolumn{11}{|l|}{$\mathrm{JP}(2,1,1)$} \\
\hline$\Delta \mathrm{CC}$ & 1.8109 & 5.3355 & $2.9292 *$ & -2.8333 & -0.1641 & $4.7593^{* *}$ & -2.3879 & 0.2427 & -0.3264 & 2.4096 \\
\hline$\Delta \mathrm{GC}$ & -1.4683 & -3.1905 & -0.4755 & -0.2985 & $0.5885^{*}$ & $-0.9965^{*}$ & -0.9036 & 0.0722 & $2.4642^{*}$ & -4.6757 \\
\hline \multicolumn{11}{|l|}{$\mathrm{KR}(2,1,1)$} \\
\hline$\Delta \mathrm{CC}$ & -6.1381 & -11.3080 & 1.2928 & 0.7606 & 0.5809 & $-6.4998^{* *}$ & 7.2187 & 2.1863 & 0.3574 & 4.9385 \\
\hline$\Delta \mathrm{GC}$ & 3.5171 & 0.7128 & -3.4635 & -3.8219 & -0.1490 & $4.5260^{* *}$ & -7.7014 & -2.7627 & -0.7090 & -0.3968 \\
\hline \multicolumn{11}{|l|}{$\operatorname{MY}(2,1,1)$} \\
\hline$\Delta \mathrm{CC}$ & 4.8710 & 4.6086 & -4.9563 & 5.2602 & $5.3417^{* *}$ & 4.9532 & 4.0891 & -3.4602 & $-4.9429^{* *}$ & $*-4.4311$ \\
\hline$\Delta \mathrm{GC}$ & -6.3353 & -3.5008 & 5.7388 & -7.4320 & $-11.7826^{* *}$ & * 3.6866 & 2.0014 & -2.0537 & 0.3126 & -2.0678 \\
\hline \multicolumn{11}{|l|}{$\mathrm{SG}(2,2,2)$} \\
\hline$\Delta \mathrm{CC}$ & 16.9579 & $14.4712^{* *}$ & $12.5581^{*}$ & 8.6506 & 43.1914 & -6.8039 & 27.6145 & $-3.8905^{* *}$ & * 4.4285 & -1.3591 \\
\hline$\Delta \mathrm{GC}$ & -21.3812 & $-8.8620^{* *}$ & $-19.7343^{* *}$ & *-15.3477 & -35.5748 & -1.6305 & -26.1213 & $-10.7091^{* *}$ & ${ }^{*}-11.4021$ & 0.2807 \\
\hline$\Delta \mathrm{CC}(-1)$ & 9.2162 & $11.2593^{* *}$ & -13.1245 & -7.0881 & 24.1866 & $-7.4145^{*}$ & 17.4657 & 0.3470 & 15.9045 & 0.3991 \\
\hline$\Delta \mathrm{GC}(-1)$ & -10.9958 & $-3.2191^{* *}$ & 3.9930 & 2.6832 & -25.2336 & 11.6920 & -1.4216 & $-5.7442^{* *}$ & -5.0585 & -3.1380 \\
\hline \multicolumn{11}{|l|}{$\mathrm{TH}(1,2,2)$} \\
\hline$\Delta \mathrm{CC}$ & 5.5860 & 2.7338 & 0.4249 & 1.6067 & 1.5007 & -30.2104 & -13.9175 & -14.7650 & -6.8708 & $5.4236^{* *}$ \\
\hline$\Delta \mathrm{GC}$ & -7.1291 & $-6.5297^{* *}$ & 0.7408 & -9.6996 & -3.9426 & 28.6527 & 2.0587 & 17.1955 & -2.3132 & $1.3378^{* *}$ \\
\hline$\Delta \mathrm{CC}(-1)$ & -14.7904 & $-4.4731^{* *}$ & -3.8167 & -10.3481 & -5.9443 & -21.8140 & -14.6094 & 4.0754 & 0.4506 & $-1.7637^{* *}$ \\
\hline$\Delta \mathrm{GC}(-1)$ & 15.5117 & 3.5432 & 6.6963 & -7.1399 & 3.0440 & 10.3618 & 4.2367 & 7.3079 & $-2.9840^{*}$ & $-2.1245^{* *}$ \\
\hline \multicolumn{11}{|l|}{$\operatorname{TW}(1,2,2)$} \\
\hline$\Delta \mathrm{CC}$ & -4.2077 & 8.0192 & -2.7326 & 1.0576 & 2.7942 & 3.2840 & 0.9854 & 14.7747 & 19.0114 & $0.9677^{* *}$ \\
\hline$\Delta \mathrm{GC}$ & 4.4717 & -4.0444 & 4.6541 & -3.4156 & -2.6856 & -4.8584 & -7.0664 & -15.7522 & -1.8032 & $-2.3841^{* *}$ \\
\hline$\Delta \mathrm{CC}(-1)$ & -2.5796 & 1.5310 & 19.7064 & -3.2729 & 0.9062 & 1.8132 & 5.0542 & 3.7106 & 13.0936 & $3.4351^{* *}$ \\
\hline$\Delta \mathrm{GC}(-1)$ & $3.8870^{*}$ & 4.3289 & -9.2260 & 0.9413 & -0.0575 & -5.2302 & -5.4931 & $9.1428^{*}$ & 0.9931 & $-3.0941^{* *}$ \\
\hline \multicolumn{11}{|l|}{$\mathrm{VN}(2,2,2)$} \\
\hline$\Delta \mathrm{CC}$ & -27.3087 & 2.5944 & -4.3403 & 0.5281 & $-3.0945^{*}$ & -8.5860 & $-4.2794^{* *}$ & ${ }^{*}-22.4521^{* *}$ & * 10.8690 & $0-0.1281$ \\
\hline$\Delta \mathrm{GC}$ & 29.2418 & 5.0413 & 3.2809 & -0.3630 & $4.3071^{*}$ & -22.9099 & -0.0486 & $26.7628^{* *}$ & * $\quad 9.4834$ & $4-3.9253$ \\
\hline$\Delta \mathrm{CC}(-1)$ & -15.1612 & 12.2267 & 11.1508 & -0.1553 & $-3.6383^{*}$ & -2.0065 & $-9.2195^{* *}$ & * $6.9357^{* *}$ & * -22.9296 & $6 \quad 0.1374$ \\
\hline$\Delta \mathrm{GC}(-1)$ & 14.7241 & -7.4980 & -11.7391 & 0.6761 & $5.2128^{* *}$ & $* \quad 10.0653$ & $10.5210^{* *}$ & * $9.8917^{* *}$ & * $\quad 7.9168$ & $84.7041^{*}$ \\
\hline
\end{tabular}

Note: ${ }^{* *} 1 \%$ significance level; * $5 \%$ significance level.

Source: Author's own work. 
economic diplomacy of the Silk Road Economic Belt underlines the role of CEE in China-EU cooperation (Liu 2014).

In the short-run relationships, only Singapore has significances on $\mathrm{CC}$ and GC, and Thailand on one-lag CC. The long run and the short run of CC and GC in Singapore show reverse effects, which may result from cross-country heterogeneity, similarly to Loayza - Ranciere's (2006) argument. Compared with the two supertrading economies (Krugman et al. 1995), Singapore and Hong Kong, called twins regarding global free trade hubs (Krause 1988), Singapore appears to be the CEE's gateway to East Asia.

Table 6 elaborates the individual cross-country coefficients and p-values in the short run. Hong Kong's role for CEE countries that enter the EA marketplaces is very important since Hong Kong has a more or less significant CC or GC for each CEE country, except for the new EU members Bulgaria and Romania. It corresponds to Ahn et al.'s (2011) evidence that Hong Kong acts as an intermediary in facilitating trade for the Chinese market. Among the three CEE tiger economies, the Czech Republic, Hungary, and Poland, only Poland shows significances in China, suggesting their dynamic relationship. The Czech Republic has a relationship with Singapore and Hong Kong, but Hungary is not influenced by the $\mathrm{CC}$ and the GC except for the significance of the GC in Hong Kong. The other least significant case is found in Bulgaria. Slovakia is dominated by the related automotive industry (Pavličková 2013); thus, the CC and the GC are significant in China, Thailand, and Taiwan, but not in Japan and South Korea, which have global car brands.

\section{CONCLUSION}

This study focused on CEE exports to EA market places during the period of 2004-2014. Regarding the very limited empirical research on the issue, this study contributes to the literature by employing the panel ARDL model to investigate the causal relationships between CEE export instability and commodity, and geographic concentrations in the EA region. Given the mixed orders of integration from the panel unit root tests, the panel ARDL co-integration procedure is an ideal method for analysis.

The results for causal relationships between export instability and trade concentrations are significant for the sample countries in the long-run estimates, but not in the short-run. The first broad conclusion is that the relationships are permanent, not temporary. This empirical evidence, on the PMG basis of a single study, confirms a long debate about no clear-cut relationship between export instability and trade concentrations. China can be regarded as a sub-region for CEE ex- 
ports to EA because of the similar effects, which is distinct from the other strong economy of Japan. Singapore and Hong Kong, the twin states of Asian business hubs, play an intermediate role for CEE exports to EA, particularly in the short run. Vietnam and South Korea display some disturbance factor of policy, while Indonesia and Malaysia perhaps have niche commodities. Intra-industry trade, for instance, of Thailand and Taiwan with Slovakia in the related automotive industry, should not be ignored.

Globalisation in international trade has dramatically broken down the barrier of geographic distance and information. Dennis - Shepherd (2011) demonstrated that a trade policy can effectively reduce transaction costs and promote export diversification. CEE countries seeking a strategy of going global may rethink enhanced cooperation with East Asia, particularly sequential FTAs between the EU and Asian countries. The study results suggest that the CEE export policy toward EA markets is likely to consider the impact of trade concentrations on export instability.

\section{REFERENCES}

Agosin, M. R. - Alvarez, R. - Bravo-Ortega, C. (2012): Determinants of Export Diversification around the World: 1962-2000. The World Economy, 35(3): 295-315.

Ahn, J. - Khandelwal, A. K. - Wei, S. J. (2011): The Role of Intermediaries in Facilitating Trade. Journal of International Economics, 84(1): 73-85.

Al-Rodhan, K. R. (2007): A Critique of the China Threat Theory: A Systematic Analysis. Asian Perspective, 31(3): 41-66.

Athukorala, P. - Huynh, F. C. H. (1987): Export Instability and Growth: Problems and Prospects for the Developing Economies. London: Croom Helm.

Awokuse, T. O. (2007): Causality between Exports, Imports, and Economic Growth: Evidence from Transition Economies. Economics Letters, 94(3): 389-395.

Baltagi, B. (2013): Econometric Analysis of Panel Data. 5th ed., New Jersey: John Wiley \& Sons.

Bijsterbosch, M. - Kolasa, M. (2010): FDI and Productivity Convergence in Central and Eastern Europe: An Industry-Level Investigation. Review of World Economics, 145(4): 689-712.

Birzins, A. (2004): Bilateral Diplomatic and Economic Relations between East Asia and the New EU Members: The Case of Latvia. Asia Europe Journal, 2(2): 221-235.

Borgersen, T. A. - King, R. M. (2014): Export-Led Growth in Transition Economies: The Role of Industrial Structure, Productivity Growth Differentials, and Cross-Sectoral Subsidies. Eastern European Economics, 52(3): 33-54.

Cadot, O. - Carrère, C. - Strauss-Kahn, V. (2014): OECD Imports: Diversification of Suppliers and Quality Search. Review of World Economics, 150(1): 1-24.

Cariolle, J. - Goujon, M. (2013): Measuring Macroeconomic Instability: A Critical Survey Illustrated with Exports Series. Journal of Economic Surveys, 29(1): 1-26.

Davis, G. - Pecar, B. (2013): Business Statistics Using Excel. Oxford: Oxford University Press.

Dennis, A. - Shepherd, B. (2011): Trade Facilitation and Export Diversification. The World Economy, 34(1): 101-122. 
Engle, R. F. - Granger, C. W. (1987): Co-Integration and Error Correction: Representation, Estimation, and Testing. Econometrica, 55(2): 251-276.

Fligstein, N. - Merand, F. (2002): Globalization or Europeanization? Evidence on the European Economy since 1980. Acta Sociologica, 45(1): 7-22.

Forgó, B. - Jevčák, A. (2015): Economic Convergence of Central and Eastern European EU Member States over the Last Decade (2004-2014). European Economy Discussion Paper, 001, European Commission Publications.

Gouvea, S. H. (2016): Export Specialisation and Output Synchronisation in the Euro Area: The Case of Southern Countries. Acta Oeconomica, 66(4): 617-637.

Hamid, Z. (2010): Concentration of Exports and Patterns of Trade: A Time-Series Evidence of Malaysia. The Journal of Developing Areas, 43(2): 255-270.

Herzer, D. - Nowak-Lehnmann, D. F. (2006): What does Export Diversification do for Growth? An Econometric Analysis. Applied Economics, 38(15): 1825-1838.

Hsiao, C. (2014): Analysis of Panel Data. 3rd ed., New York: Cambridge University Press.

IHS (2015): Eviews 9 User's Guide II. California: IHS Global Inc.

Japan Center for International Exchange - University of Helsinki (2006): ASEM in Its Tenth Year: Looking Back, Looking forward - An Evaluation of ASEM in Its First Decade and an Exploration of Its Future Possibilities. Tokyo: Japan Center for International Exchange.

Kali, R. - Méndez, F. - Reyes, J. (2007): Trade Structure and Economic Growth. The Journal of International Trade \& Economic Development, 16(2): 245-269.

Kamat, M. M. (2016): Iron-Ore Export Instability and the Market Concentration: Temporo-Spatial Analysis in a Regional Context. Asian Journal of Research in Marketing, 5(3): 1-15.

Katrak, H. (1973): Commodity Concentration and Export Fluctuations: A Probability Analysis. The Journal of Development Studies, 9(4): 556-565.

Korhonen, P. (2012): Changing Definitions of Asia. Asia Europe Journal, 10(2-3): 99-112.

Krause, L. B. (1988): Hong Kong and Singapore: Twins or Kissing Cousins? Economic Development and Cultural Change, 36(3): 45-66.

Krugman, P. - Cooper, R. N. - Srinivasan, T. N. (1995): Growing World Trade: Causes and Consequences. Brookings Papers on Economic Activity, 1995(1): 327-377.

Lee, K. H. (1977): Export Structure and Export Instability: The Case of Peninsular Malaysia. The Developing Economies, 15(3): 320-331.

Leitner, S. M. - Stehrer, R. (2014): Trade Integration, Production Fragmentation and Performance in Europe - Blessing or Curse? A Comparative Analysis of the New Member States and the EU15. Vienna: Wiener Institut für Internationale Wirtschaftsvergleiche (WIIW).

Liu, Z. (2014): The Role of Central and Eastern Europe in Building of Silk Road Economic Belt. China Institute of International Studies. http://www.ciis.org.cn/english/2014-09/18/ content_7243192.htm (accessed 25 Nov 2015).

Loayza, N. V. - Ranciere, R. (2006): Financial Development, Financial Fragility, and Growth. Journal of Money, Credit and Banking, 38(4):1051-1076.

Love, J. (1979): Trade Concentration and Export Instability. Journal of Development Studies, 15(3): 60-69.

Love, J. (1985): Export Instability: An Alternative Analysis of Causes. The Journal of Development Studies, 21(2): 244-252.

Love, J. (1986): Commodity Concentration and Export Earnings Instability: A Shift from CrossSection to Time Series Analysis. Journal of Development Economics, 24(2): 239-248.

Love, J. (1987): Export Instability in Less Developed Countries: Consequences and Causes. Journal of Economic Studies, 14(2): 3-80. 
MacBean, A. I. - Nguyen, D. T. (1980): Commodity Concentration and Export Earnings Instability: A Mathematical Analysis. The Economic Journal, 90(358): 354-362.

Malhotra, N. - Pinky (2012): Growth, Structure and Instability of India's Exports. Journal of International Economics, 3(2): 57-72.

Malhotra, N. - Pinky (2015): Sources of Export Instability in India. Journal of International Economics, 6(1): 58-72.

Malik, A. - Temple, J. R. (2009): The Geography of Output Volatility. Journal of Development Economics, 90(2): 163-178.

Martin, R. (1998): Central and Eastern Europe and the International Economy: The Limits to Globalisation. Europe-Asia Studies, 50(1): 7-26.

Massell, B. F. (1964): Export Concentration and Fluctuations in Export Earnings: A Cross-Section Analysis. The American Economic Review, 54(2): 47-63.

Massell, B. F. (1970): Export Instability and Economic Structure. The American Economic Review, 60(4): 618-630.

Matura, T. (2014): Central Europe and the Republic of Korea: Politics, Economy, and Perceptions. Journal of Contemporary Korean Studies, 1(1): 173-193.

Medve-Bálint, G. (2014): The Role of the EU in Shaping FDI Flows to East Central Europe. Journal of Common Market Studies, 52(1): 35-51.

Naya, S. (1973): Fluctuations in Export Earnings and Economic Patterns of Asian Countries. Economic Development and Cultural Change, 21(4): 629-641.

Newfarmer, R. S. - Shaw, W. - Walkenhorst, P. (eds). (2009): Breaking into New Markets: Emerging Lessons for Export Diversification. Washington, D.C.: The World Bank.

Parteka, A. (2013a): The Evolving Structure of Polish Exports (1994-2010) - Diversification of Products and Trade Partners. Bank $i$ Kredyt, 44(5): 435-466.

Parteka, A. (2013b): Trade Diversity and Stages of Development - Evidence on EU Countries. Ekonomia, 30: 23-44.

Pavličková, V. (2013): The Competitiveness of Slovak Foreign Trade in the European Market. Economic Annals, 58(196): 7-49.

Pesaran, M. H. - Shin, Y. (1998): An Autoregressive Distributed-Lag Modelling Approach to Cointegration Analysis. Econometric Society Monographs, 31: 371-413.

Pesaran, M. H. - Shin, Y. - Smith, R. P. (1999): Pooled Mean Group Estimation of Dynamic Heterogeneous Panels. Journal of the American Statistical Association, 94(446): 621-634.

Poncet, S. - Mayneris, F. (2013): French Firms Penetrating Asian Markets: Role of Export Spillovers. Journal of Economic Integration, 28: 354-374.

Samen, S. (2010): A Primer on Export Diversification: Key Concepts, Theoretical Underpinnings and Empirical Evidence. Growth and Crisis Unit, The World Bank. http://blogs.worldbank.org/ files/growth/EXPORT_DIVERSIFICATION_A_PRIMER_May2010.pdf (accessed 12 July 2016).

Shepotylo, O. (2013): Export Diversification across Countries and Products: Do Eastern European (EE) and Commonwealth of Independent States (CIS) Countries Diversify Enough? The Journal of International Trade \& Economic Development, 22(4): 605-638.

Silgoner, M. - Steiner, K. - Wörz, J. - Schitter, C. (2015): Fishing in the Same Pool: Export Strengths and Competitiveness of China and Central, Eastern and South-Eastern Europe at the EU-15 Market. China Economic Review, 32: 68-83.

Stein, L. (1977): Export Instability and Development: A Review of Some Recent Findings. PSL Quarterly Review, 30(122): 279-290.

Tegene, A. (1990): Commodity Concentration and Export Earnings Instability: The Evidence from African Countries. The American Economist, 34(2): 55-59. 
Weber, E. (2011): Foreign and Domestic Growth Drivers in Eastern Europe. Economic Systems, 35(4): 512-522.

Welle-Strand, A. - Vlaicu, M. - Tjeldvoll, A. (2013): Vietnam - A New Economic Dragon in Southeast Asia? Journal of Developing Societies, 29(2): 155-187.

Wooldridge, J. M. (2010): Econometric Analysis of Cross Section and Panel Data, $2^{\text {nd }}$ ed. Massachusetts: The MIT Press.

Zhang, W. W. (2005): Overseas Chinese and the Concept of "Greater China". Refugee Survey Quarterly, 24(4): 65-73. 